
\title{
TIE2-expressing monocytes and M2-polarized macrophages impact survival and correlate with angiogenesis in adenocarcinoma of the pancreas
}

\author{
Georgi Atanasov1,2,3,*, Charlotte Pötner ${ }^{1, *}{ }^{,}$, Gabriela Aust ${ }^{4}$, Katrin Schierle ${ }^{5}$, Corinna \\ Dietel $^{1}$, Christian Benzing ${ }^{1,2}$, Felix Krenzien ${ }^{1,2,3}$, Michael Bartels ${ }^{1,6}$, Uwe Eichfeld ${ }^{1}$, \\ Moritz Schmelzle ${ }^{1,2}$, Marcus Bahra ${ }^{2}$, Andreas Pascher ${ }^{2}$ and Georg Wiltberger ${ }^{1,7}$ \\ ${ }^{1}$ Department of Visceral, Transplantation, Thoracic and Vascular Surgery, University Hospital Leipzig, Leipzig, Germany \\ ${ }^{2}$ Department of Surgery, Campus Charité Mitte und Campus Virchow-Klinikum, Charité, Universitätsmedizin Berlin, Berlin, \\ Germany \\ ${ }^{3}$ Berlin Institute of Health, Berlin, Germany \\ ${ }^{4}$ Department of Surgery, Research Laboratories, University of Leipzig, Leipzig, Germany \\ ${ }^{5}$ Institute of Pathology, University Hospital Leipzig, Leipzig, Germany \\ ${ }^{6}$ Department of General and Visceral Surgery, Helios Clinic Leipzig, Leipzig, Germany \\ ${ }^{7}$ Department of General, Visceral and Transplantation Surgery, University Hospital of RWTH Aachen, Aachen, Germany \\ *These authors contributed equally to this work \\ Correspondence to: Georgi Atanasov, email: georgi.atanasov@charite.de \\ Keywords: TIE2-expressing monocytes; pancreatic adenocarcinoma; tumor-associated macrophages; M2-macrophages; angiogenesis \\ Received: December 15, $2017 \quad$ Accepted: June 12, $2018 \quad$ Published: July 03, 2018 \\ Copyright: Atanasov et al. This is an open-access article distributed under the terms of the Creative Commons Attribution License \\ 3.0 (CC BY 3.0), which permits unrestricted use, distribution, and reproduction in any medium, provided the original author and \\ source are credited.
}

\section{ABSTRACT}

Introduction: M2-polarized tumor-associated macrophages (TAMs) and TIE2expressing monocytes (TEMs) are associated with angiogenesis and have been identified as a potential prognostic marker in several solid tumors, including hepatobiliary malignancies. However, little is known regarding their influence on tumor progression and patient survival in pancreatic ductal adenocarcinoma (PDAC).

Results: Patients with tumors characterized by the presence of $\mathrm{CD} 163^{+}$TAMs or TEMs in TCA or TIF, respectively, showed a significantly decreased 1-, 3- and 5-year overall and recurrence-free survival compared to patients without CD163+ ${ }^{+}$TAMs or TEMs (all $\rho<0.05$ ). Patients with TEMs in TCA showed a higher incidence of tumor recurrence $(\rho<0.05)$. Furthermore, the presence of $\mathrm{CD} 163^{+}$TAMs was associated with a higher tumor MVD $(\rho<0.05)$.

Conclusions: Presence of M2-polarized TAMs and TEMs is associated with a decreased overall and recurrence-free survival of patients with PDAC.

Materials and methods: The localization and density of $\mathrm{CD} 163^{+} \mathrm{M2-polarized}$ TAMs and TEMs were quantified in the tumor central area (TCA) and tumor-infiltrating front (TIF) in human PDAC tissue $(n=106)$ and correlated to clinicopathological characteristics, tumor recurrence rates and patient survival. In parallel, tumor microvascular density (MVD) and the density of angiopoietin-positive tumor cells were quantified. Statistical analysis was performed using SPSS software. 


\section{INTRODUCTION}

Solid cancers harbor different subpopulations of immune cells, each of which has the potential for pro- or anti-tumor functions. Macrophages are the predominant immune cell population found throughout tumors and macrophage numbers or functions can be modulated in order to augment anti-cancer therapies [1]. The immune activation state of these tumor-associated macrophages (TAMs) can be divided into M1- (anti-cancer function) and M2-type (pro-tumoral or immunosuppressive) [2]. Various escape mechanisms deployed by malignant cells and the tumor microenvironment (TME) mediate the conversion of infiltrating macrophages into immunosuppressive and pro-tumoral M2 TAMs [3]. Therefore, understanding and targeting the specific pathways associated with the M2 polarization state of TAMs is a promising approach for therapeutic strategies.

As previously reported by us, a differential influence and functionality of localized tumor sites in TME, i.e. tumor central area (TCA) and tumor invasive front (TIF), on related immunologic responses play a key role in cancer immunity and tumor progression [4]. TAMs localized in TCA or TIF can impact oncogenesis in an opposite manner. High TAMs frequency in TCA is associated with poor prognosis in hepatocellular carcinoma (HCC), esophageal, ovarian and breast cancer [5-10]. By contrast, TAMs in TIF in colonic, gastric, and endometrial cancer correlate with a favorable outcome [11-13]. TME, tumorderived factors and escape mechanisms facilitate tumor growth, neovascularization, and metastasis. However, a constant interplay between immune responses in TCA or TIF and infiltrating TAMs and their polarization states, plays a key role in this process.

Tumor angiogenesis is a major factor in the development and progression of cancer and therefore inhibiting it is a promising therapeutic target [14]. Members of the angiopoietin (Ang) family are potent growth factors and important modulators of tumor angiogenesis but could represent functional antagonists as well [15]. Monocytes/ macrophages are primary producers of angiogenic mediators in oncogenesis [16-17]. Bone marrow (BM)-derived myeloid cells contribute significantly to tumor angiogenesis [18]. In both mice and humans, a subset of proangiogenic circulating and tumor-infiltrating monocytes expressing functionally active Ang receptor TIE2 have been recently identified [19]. These Tie2-expressing monocytes (TEMs) are selectively recruited to tumors, foster neoangiogenesis, and oncogenesis, but are not found in non-cancerous tissues $[20,21]$. We have previously demonstrated that in respect to tumor vascularization grade, monocyte localization in TCA or TIF and related cancer immunity, these tumor-infiltrating TEMs and TAMs can impact survival and prognosis in an opposite manner [4, 22, 23].

Clinical significance of angiogenic TEMs and M2polarization state of infiltrating TAMs has been suggested for human malignancies, where the interplay between tumor immunology and angiogenesis plays a key role in oncogenesis [20]. Recently, we showed that tumor Ang density, corresponding angiogenic TEMs and infiltrating TAMs impact patent survival and exert prognostic significance in primary hepatic tumors and hilar cholangiocarcinomas $[4,22,23]$. However, the importance of these immune markers in pancreatic ductal adenocarcinoma (PDAC) is unknown. The aim of this study was therefore to evaluate the importance of M2-polarized TAMs, Angs and related Ang-receptor bearing TEMs and their association with tumor angiogenesis, tumor growth, metastasis, recurrence and clinical prognosis in human PDAC.

\section{RESULTS}

The overall 1-, 3- and 5-year survival of our cohort was $81.2,44.9$ and $41.8 \%$, respectively. The recurrencefree 1-, 3- and 5- year survival rates were 75.7, 45.1 and $43.9 \%$, respectively. Sixty-four out of the $106(64 / 106$, $60.4 \%$ ) patients died within the follow-up interval. In $52 / 106$ patients $(49.1 \%)$ tumor recurrence was diagnosed and 40/106 (37.7\%) patients died of recurrent disease. Local tumor recurrence was detected in 20/106 (18.9\%) patients. In 50/106 (45.9\%) patients distant metastases were seen (Table 1). 15/106 (14.1\%) patients had a local recurrence and metastatic disease. Nineteen/106 (17.9\%) patients died from other causes and had no signs of tumor recurrence at the time of death.

\section{TEMs, TAMs and angiopoietin distribution in PDAC}

Typical images for the tissue distribution of TEMs, $\mathrm{CD}^{2} 8^{+}$or $\mathrm{CD} 163^{+} \mathrm{TAMs}$ and angiopoietins are shown in Figure $1 \mathrm{~A}-1 \mathrm{H}$, the respective statistical evaluation of all patients is summarized in Tables 2, 3 and 4. TEMs are preferentially located in areas of tumor neovascularization, but not in tumor necrosis regions (Figure 1A-1B). CD68 ${ }^{+}$ or $\mathrm{CD} 163^{+}$TAMs showed a uniform density in the tumor stroma, TCA, TIF and were also present in necrotic tumor regions (Figure 1C-1D). The pattern of TEMs and $\mathrm{CD} 163^{+}$ TAMs displayed a preference for the tumor perivascular areas (Figure 1A). High Ang density (Figure 1E-1F) was not frequently observed in PDAC, as most cases showed Ang low abundance. In contrast, most of PDAC samples displayed high tumor microvascular density (MVD) (Figure 1G-1H).

\section{TEMs associate with metastatic disease and tumor recurrence in PDAC}

The presence of TEMs in the TCA was associated with an enhanced incidence of metastatic disease (Figure 1A-1B, Tables 2 and 4). In the TEM ${ }^{+}$group 6/7 (85.7\%) and in the TEM group 41/99 (41.4\%) patients had 
Table 1: Clinicopathological characteristics of the patients included in the study

\begin{tabular}{|c|c|}
\hline \multicolumn{2}{|c|}{ Clinicopathological characteristics } \\
\hline Variable & Value (\%) \\
\hline No. of patients & 106 \\
\hline \multicolumn{2}{|l|}{ Gender } \\
\hline Female & $41(38.7 \%)$ \\
\hline Male & $65(61.3 \%)$ \\
\hline \multicolumn{2}{|l|}{ Patient age } \\
\hline$\leq 60$ & $55(51.9 \%)$ \\
\hline$>60$ & $51(48.1 \%)$ \\
\hline \multicolumn{2}{|l|}{ Pathologic T stage } \\
\hline $\mathrm{T} 1 / \mathrm{T} 2$ & $22(20.8 \%)$ \\
\hline T3/T4 & $84(79.2 \%)$ \\
\hline \multicolumn{2}{|l|}{ Pathologic N stage } \\
\hline Positive & $32(30.2 \%)$ \\
\hline Negative & $74(69.8 \%)$ \\
\hline \multicolumn{2}{|c|}{ Lymphangiosis carcinomatosa } \\
\hline Positive & $23(21.7 \%)$ \\
\hline Negative & $83(78.3 \%)$ \\
\hline \multicolumn{2}{|l|}{ Angionvasion } \\
\hline Positive & $29(74.5 \%)$ \\
\hline Negative & $27(25.5 \%)$ \\
\hline \multicolumn{2}{|c|}{ Perineural sheath infiltration } \\
\hline Positive & $35(33.0 \%)$ \\
\hline Negative & $71(67.0 \%)$ \\
\hline \multicolumn{2}{|c|}{ Pathologic R-Category } \\
\hline R0 & $82(77.4 \%)$ \\
\hline $\mathrm{R} 1 / \mathrm{R} 2$ & $24(22.6 \%)$ \\
\hline \multicolumn{2}{|c|}{ Histologic differentiation } \\
\hline Well & $4(3.8 \%)$ \\
\hline Moderate/Poor & $102(96.2 \%)$ \\
\hline \multicolumn{2}{|l|}{ Distant metastases } \\
\hline With & $47(44.3 \%)$ \\
\hline Without & $59(55.7 \%)$ \\
\hline \multicolumn{2}{|l|}{ Liver metastases } \\
\hline With & $27(25.5 \%)$ \\
\hline Without & $79(74.5 \%)$ \\
\hline \multicolumn{2}{|l|}{ Tumor recurrence } \\
\hline With & $52(49.1 \%)$ \\
\hline Without & $54(50.9 \%)$ \\
\hline \multicolumn{2}{|l|}{ Local recurrence } \\
\hline With & $20(18.9 \%)$ \\
\hline Without & $86(81.1 \%)$ \\
\hline
\end{tabular}

distant metastases $(\rho=0.023)$. Interestingly, a significant association between infiltrating TEMs and presence of hepatic metastases was observed: 76/99 (76.8\%) patients of the $\mathrm{TEM}^{-}$group had no distant metastases in the liver $(\rho=0.047)$. The presence of TEMs did not correlate to other clinicopathologic parameters or to Ang expression in PDAC. The frequency of CD68 ${ }^{+}$TAMs in TCA or TIF was not associated with the studied parameters.

\section{M2-polarized TAMs associate with enhanced tumor neovascularization in PDAC}

The presence of $\mathrm{CD}_{163^{+}}$TAMs in TIF was associated with the MVD (Tables 3 and 4). In the CD163 $\mathrm{TAM}^{+}$group 19/23 (82.6\%) patients, whereas in the $\mathrm{CD} 163^{+} \mathrm{TAM}^{-}$group only $24 / 59(47.0 \%)$ patients showed $\operatorname{MVD}^{\text {high }}(\rho=0.046)$. Interestingly, TEMs in TCA and 
Table 2: Correlation of TIE2-expressing monocytes in tumor central area with clinicopathological characteristics of pancreatic adenocarcinoma

\section{Clinicopathological analysis}

\begin{tabular}{|c|c|c|c|}
\hline Variable & TEMs pos & TEMs neg & $p$ \\
\hline No. of patients & 7 & 99 & \\
\hline Gender & & & 0.570 \\
\hline Female & $2(21.6 \%)$ & $39(39.4 \%)$ & \\
\hline Male & $5(71.4 \%)$ & $60(60.6 \%)$ & \\
\hline Patient age, years & & & 0.621 \\
\hline$>60$ & $4(57.1 \%)$ & $47(47.5 \%)$ & \\
\hline$\leq 60$ & $3(42.9 \%)$ & $52(52.2 \%)$ & \\
\hline Pathologic T stage & & & 0.662 \\
\hline $\mathrm{T} 1 / \mathrm{T} 2$ & $1(14.3 \%)$ & $21(21.2 \%)$ & \\
\hline T3/T4 & $6(85.7 \%)$ & $78(78.8 \%)$ & \\
\hline Pathologic N stage & & & 0.072 \\
\hline Positive & $0(00.0 \%)$ & $32(32.3 \%)$ & \\
\hline Negative & $7(100.0 \%)$ & $67(67.7 \%)$ & \\
\hline Lymphangiosis carcinomatosa & & & 0.150 \\
\hline Positive & $0(00.0 \%)$ & $23(23.2 \%)$ & \\
\hline Negative & $7(100.0 \%)$ & $76(76.8 \%)$ & \\
\hline Angioinvasion & & & 0.482 \\
\hline With & $6(85.7 \%)$ & $73(73.7 \%)$ & \\
\hline Without & $1(14.3 \%)$ & $26(26.3 \%)$ & \\
\hline Perineural sheath infiltration & & & 0.796 \\
\hline Positive & $2(28.6 \%)$ & $33(33.3 \%)$ & \\
\hline Negative & $5(71.4 \%)$ & $66(66.7 \%)$ & \\
\hline Pathologic R-category & & & 0.585 \\
\hline R0 & $6(85.7 \%)$ & $76(76.8 \%)$ & \\
\hline $\mathrm{R} 1 / \mathrm{R} 2$ & $1(14.3 \%)$ & $23(23.2 \%)$ & \\
\hline Histologic differentiation & & & 0.588 \\
\hline Well & $0(00.0 \%)$ & $4 \quad(4.0 \%)$ & \\
\hline Moderate/poor & $7(100.0 \%)$ & $95(96.0 \%)$ & \\
\hline Distant metastases & & & 0.023 \\
\hline With & $6(85.7 \%)$ & $41(41.4 \%)$ & \\
\hline Without & $1(14.3 \%)$ & $58(58.6 \%)$ & \\
\hline Liver metastases & & & 0.047 \\
\hline With & $4(57.1 \%)$ & $23(23.2 \%)$ & \\
\hline Without & $3(42.9 \%)$ & $76(76.8 \%)$ & \\
\hline Tumor recurrence & & & 0.045 \\
\hline With & $6(85.7 \%)$ & $46(46.5 \%)$ & \\
\hline Without & $1(14.3 \%)$ & $53(53.5 \%)$ & \\
\hline Local recurrence & & & 0.093 \\
\hline With & $3(42.9 \%)$ & $17(17.2 \%)$ & \\
\hline Without & $4(57.1 \%)$ & $82(82.8 \%)$ & \\
\hline MVD & & & 0.255 \\
\hline
\end{tabular}




$\begin{array}{lccc}\text { High } & 6(85.7 \%) & 64(64.6 \%) & \\ \text { Low } & 1(14.3 \%) & 35(35.4 \%) & \mathbf{0 . 0 0 2} \\ \text { CD163-positive } & & & \\ \text { TAMs in TIF } & & 56(36.0 \%) & \\ \text { Positive } & 1(50.0 \%) & 17(64.0 \%) & \\ \text { Negative } & 5(50.0 \%) & & \\ \text { CD68-positive } & & & \\ \text { TAMs in TCA } & & 43(43.4 \%) & \\ \text { Positive } & 4(57.1 \%) & 56(56.6 \%) & \\ \text { Negative } & 3(42.9 \%) & \end{array}$

CD163 ${ }^{+}$TAMs in TIF were strongly associated: in the TIF CD163+ TAM- group 56/59 (98.2\%) patients were TEMwhereas 17/23 (77.3\%) patients in the TIF CD163+ ${ }^{+} \mathrm{TAM}^{+}$ group were $\operatorname{TEM}^{+}$in the TCA $(\rho=0.002)$.

\section{Angiopoietin-2 expression associates with perineural sheet infiltration in PDAC}

Ang-2 expression in TCA correlated with the incidence of perineural sheet infiltration $(\rho=0.002)$ (Figure 1E-1F, Table 4). In the ANG2 $2^{\text {low }}$ group, only $20 / 80$ $(25.0 \%)$ patients showed a perineural sheet infiltration, whereas in the ANG2 ${ }^{\text {high }}$ group 11/26 (42.3\%) patients had this phenomenon. Ang-1 expression in TCA was associated inversely with perineural sheet infiltration $(\rho=0.038)$ : in the ANG1 $1^{\text {high }}$ group, $31 / 39(79.5 \%)$ had no perineural sheet infiltration.

\section{Influence of TIE2-expressing monocytes and M2-polarized macrophages on survival in PDAC}

Patient survival was decreased in patients with $\mathrm{CD} 163^{+}$TAMs in TCA $(p=0.041)$ or TIF $(p=0.021)$ when compared to patients without these cells in both tumor sites. The overall 1-, 3- and 5-year survival rates were $100,84.3$ and $84.3 \%$ in patients of the $\mathrm{CD} 163^{+}$ TAM $^{-}$group compared to $76.2,45.1$ and $39.9 \%$ in the $\mathrm{CD} 163^{+} \mathrm{TAM}^{+}$group, respectively, when considering the TIF (Figure 2A) or TCA (data not shown). Furthermore, the absence of $\mathrm{CD} 163^{+}$TAMs in TIF correlated with an improved recurrence-free survival. The 1-, 3-, and 5-year recurrence-free survival of patients without $\mathrm{CD} 163^{+} \mathrm{TAMs}$ were higher $(82.4,53.2$, and $53.2 \%)$ compared to patients with $\mathrm{CD} 163^{+}$TAMs $(58.1,43.7$, and $37.6 \%$ ), respectively $(p=0.022$; Figure 2B).

The 1-, 3-, and 5-year recurrence-free survival of patients without TEMs in TCA (77.6, 51.8 and $49.9 \%)$ were higher compared to patients with TEMs $(42.9,21.7$ and $21.7 \%$ ), respectively ( $p=0.012$; Figure $2 \mathrm{C}$ ). The presence of $\mathrm{CD}^{+} 8^{+}$TAMs was not associated with patient survival (data not shown).

\section{DISCUSSION}

Analyzing tissue density of infiltrating M2-polarized TAMs, TEMs, and Angs in tumor samples from patients who underwent resection for PDAC, we demonstrated that (1.) Ang density associates with perineural sheet infiltration (2.) angiogenic TEMs and M2-polarized TAMs are differentially expressed in PDAC, (3.) correlate with metastatic spread and tumor recurrence, (4.) associate with angiogenesis, and (5.) impact survival rates.

The mechanisms that enable solid cancers to escape elimination by the immune system remain unclear, but their elucidation may provide novel therapeutic interventions. Host immune function in TME, i.e. TCA and TIF, is shaped by tissue-specific and tumor-derived signals that reduce the potency of anti-tumor immune competence. This is particularly relevant in human oncogenesis where immune tumor infiltration with macrophage/monocyte subsets heavily affects prognosis [24]. M2 TAMs and TEMs express functional receptors of angiogenesis, build up to $50 \%$ of the tumor volume, exert a significant impact on cancer-related inflammation and angiogenesis, inhibit anti-tumor response, and facilitate tumor escape mechanisms, metastasis and tumor progression [25].

There is a scarce amount of data on the presence of TEMs and their correlation with clinicopathologic characteristics in human tumors. Furthermore, the significance of TEMs to date is established mainly regarding their circulating population in human blood [26, 27]. The few published studies failed to demonstrate a prognostic value of infiltrating TEMs in solid cancerous tissue. To our knowledge, the presented work is the first to document TEMs presence and importance in PDAC. Intratumoral visualization of TEMs using immunoreactivity revealed abundance in TCA and TIF, and a preferential localization in proximity to microvasculature, as well. Of note, as reported by us previously for other human cancers, a considerable amount of PDAC samples exhibited an absence of TEMs in solid cancerous tissue [23].

In our work presence of TEMs and M2 TAMs impacted patient survival after resection of PDAC. 
Table 3: Correlation of CD163-positive TAMs in the tumor invasive front with clinicopathological characteristics of pancreatic adenocarcinoma

Clinicopathological analysis

\begin{tabular}{|c|c|c|c|}
\hline Variable & CD163 pos & CD163 neg & $p$ \\
\hline No. of patients & 23 & 59 & \\
\hline Gender & & & 0.127 \\
\hline Female & $12(52.2 \%)$ & $20(33.9 \%)$ & \\
\hline Male & $11(47.8 \%)$ & $39(66.1 \%)$ & \\
\hline Patient age, years & & & 0.817 \\
\hline$>60$ & $10(43.5 \%)$ & $24(40.7 \%)$ & \\
\hline$\leq 60$ & $13(56.5 \%)$ & $35(59.3 \%)$ & \\
\hline Pathologic T stage & & & 0.254 \\
\hline $\mathrm{T} 1 / \mathrm{T} 2$ & $6(26.1 \%)$ & $9(15.3 \%)$ & \\
\hline T3/T4 & $17(73.9 \%)$ & $50(84.7 \%)$ & \\
\hline Pathologic N stage & & & 0.495 \\
\hline Positive & $6(26.1 \%)$ & $20(33.9 \%)$ & \\
\hline Negative & $17(73.9 \%)$ & $39(66.1 \%)$ & \\
\hline Lymphangiosis carcinomatosa & & & 0.284 \\
\hline Positive & $3(13.0 \%)$ & $14(23.7 \%)$ & \\
\hline Negative & $20(87.0 \%)$ & $45(76.3 \%)$ & \\
\hline Angioinvasion & & & 0.123 \\
\hline With & $21(91.3 \%)$ & $45(76.3 \%)$ & \\
\hline Without & $2(8.7 \%)$ & $14(23.7 \%)$ & \\
\hline Perineural sheath infiltration & & & 0.178 \\
\hline Positive & $5(21.7 \%)$ & $22(37.3 \%)$ & \\
\hline Negative & $18(78.3 \%)$ & $37(62.7 \%)$ & \\
\hline Pathologic R-category & & & 0.641 \\
\hline R0 & $19(82.6 \%)$ & $46(78.0 \%)$ & \\
\hline $\mathrm{R} 1 / \mathrm{R} 2$ & $4(17.4 \%)$ & $13(22.0 \%)$ & \\
\hline Histologic differentiation & & & 0.271 \\
\hline Well & $0(0.0 \%)$ & $3(5.1 \%)$ & \\
\hline Moderate/poor & $23(100.0 \%)$ & $56(94.9 \%)$ & \\
\hline Distant metastases & & & 0.074 \\
\hline With & $14(60.9 \%)$ & $23(39.0 \%)$ & \\
\hline Without & $9(39.1 \%)$ & $36(61.0 \%)$ & \\
\hline Liver metastases & & & 0.052 \\
\hline With & $9(39.1 \%)$ & $11(18.6 \%)$ & \\
\hline Without & $14(60.9 \%)$ & $48(81.4 \%)$ & \\
\hline Tumor recurrence & & & 0.085 \\
\hline With & $15(65.2 \%)$ & $26(44.1 \%)$ & \\
\hline Without & $8(34.8 \%)$ & $33(55.9 \%)$ & \\
\hline Local recurrence & & & 0.977 \\
\hline With & $5(21.7 \%)$ & $13(22.0 \%)$ & \\
\hline Without & $18(78.3 \%)$ & $46(78.0 \%)$ & \\
\hline MVD & & & 0.046 \\
\hline
\end{tabular}



High
$4(17.4 \%)$
$24(40.7 \%)$
Low
$19(82.6 \%)$
35 (59.3\%)

CD68-positive

0.480

TAMs in TCA

Positive

15 (65.2\%)

$41(71.9 \%)$

Negative

$8(34.8 \%)$

$16(28.1 \%)$

Table 4: Patient groups and scoring in patients with pancreatic adenocarcinoma $(n=106)$

\begin{tabular}{|c|c|c|c|c|}
\hline Antigen(s) & Use & Tumor area & Groups/number of patients & \\
\hline angiopoetin-1 & $\begin{array}{l}\text { determination of } \\
\text { angiopoetin- } 1 \text { in } \\
\text { tumor cells }\end{array}$ & TCA & $\begin{array}{c}\text { ANG1 }{ }^{\text {high }} \\
\text { score 1: positive } \\
n=39\end{array}$ & $\begin{array}{c}\text { ANG1 }{ }^{\text {low }} \\
\text { score } 0: \text { negative } \\
n=67\end{array}$ \\
\hline angiopoetin-2 & $\begin{array}{l}\text { determination of } \\
\text { angiopoetin-2 in } \\
\text { tumor cells }\end{array}$ & TCA & $\begin{array}{c}\text { ANG2 } 2^{\text {high }} \\
\text { score 1: positive } \\
n=26\end{array}$ & $\begin{array}{c}\mathrm{ANG} 2^{\text {low }} \\
\text { score } 0 \text { : negative } \\
n=80\end{array}$ \\
\hline CD14, TIE2 & $\begin{array}{c}\text { determination of } \\
\text { TEMs }\end{array}$ & TCA & $\begin{array}{c}\text { positive/presence of TEMs (in } \\
\text { short: } \text { TEM }^{+} \text {) } \\
n=99\end{array}$ & $\begin{array}{c}\text { negative/absence of TEMs (in } \\
\text { short: } \text { TEM }^{-} \text {) } \\
n=7\end{array}$ \\
\hline CD31 & $\begin{array}{l}\text { determination of } \\
\text { tumor MVD }\end{array}$ & $\begin{array}{l}\text { area of highest } \\
\text { MVD, "vascular } \\
\text { hot spot" }\end{array}$ & $\begin{array}{c}\operatorname{MVD}^{\text {high }}(\geq 50 \text { microvessels } / 10 \\
\text { optical fields) } \\
n=69\end{array}$ & $\begin{array}{c}\operatorname{MVD}^{\text {low }}(<50 \text { microvessels } / 10 \\
\text { optical fields }) \\
n=37\end{array}$ \\
\hline CD68 & $\begin{array}{c}\text { determination of } \\
\text { TAMs }\end{array}$ & TIF & $\begin{array}{c}\text { positive/presence of } \mathrm{CD}^{+} 8^{+} \\
\text {TAMs (in short: } \mathrm{CD}^{+} 8^{+} \mathrm{TAM}^{+} \text {) } \\
n=73\end{array}$ & $\begin{array}{c}\text { negative/absence of } \mathrm{CD}^{+} 8^{+} \\
\text {TAMs } \\
\text { (in short: } \mathrm{CD}^{+} 8^{+} \mathrm{TAM}^{-} \text {) } \\
n=9\end{array}$ \\
\hline CD163 & $\begin{array}{c}\text { M2-polaryzation } \\
\text { of TAMs }\end{array}$ & TIF & $\begin{array}{c}\text { positive/presence of } \mathrm{CD} 163^{+} \\
\text {TAMs (in short: CD163+ } \mathrm{TAM}^{+} \text {) } \\
n=23\end{array}$ & $\begin{array}{c}\text { negative/absence of } \mathrm{CD} 163^{+} \\
\text {TAMs } \\
\text { (in short: } \mathrm{CD} 163^{+} \mathrm{TAM}^{-} \text {) } \\
n=59\end{array}$ \\
\hline
\end{tabular}

Abbreviations: MVD: microvascular density; TAM: tumor associated macrophage; TCA: tumor central area; TEM: Tie2expressing monocyte; TIF: tumor infiltrating front.

Multivariate analysis showed that tumor recurrence is an independent predictive factor for survival in patients with resectable PDAC (data not shown). Therefore, the positive correlation between infiltrating TEMs and recurrent disease supports the notion that TEMs may be a prognostic marker in patients with PDAC. In support of this, we found that patients with a higher TEMs frequency are at a greater risk of developing metastatic disease and especially liver metastases. Of note, the latter usually precludes curative surgery and in these cases patients are treated with systemic therapy for disease control. Taken together, these data implicate the potential use of TEMs and $\mathrm{CD} 163^{+}$TAMs as possible biomarkers in PDAC that could help deliver more individualized diagnostic and therapeutic modalities.
Members of the Ang family of angiogenic growth factors are potent regulators of blood- and lymphangiogenesis [28]. In agreement with previous reports, delineating a negative impact of Ang-2 in PDAC, in the current work Ang-2 frequency associated with increased incidence of perineural sheet infiltration [29]. However, we have previously shown Ang-1 to be associated beneficial tumor characteristics in other hepatobiliary malignancies [23]. In line with this, in the current work Ang-1 distribution revealed an inverse correlation with incidence of perineural sheet infiltration. Taken together our data is in concordance with published results indicating functional antagonism within the human angiopoietin axis.

The descriptive nature of the presented results represents a limitation of the current work. Thus, 
functional tests, such as in vitro co-culturing of TEMs and tumor-derived factors/tumor cells to measure and verify M2-related phenotype and responses will allow a greater understanding of this proposed interaction. This could help deliver novel strategies for adjunct treatments to augment the efficacy of checkpoint blockade inhibitors or more standard chemotherapies, radiation, and surgery.

In summary, in the current work M2-polarized TAMs, related angiopoietin-axis and corresponding Ang-receptor bearing TEMs associated with established clinicopathologic

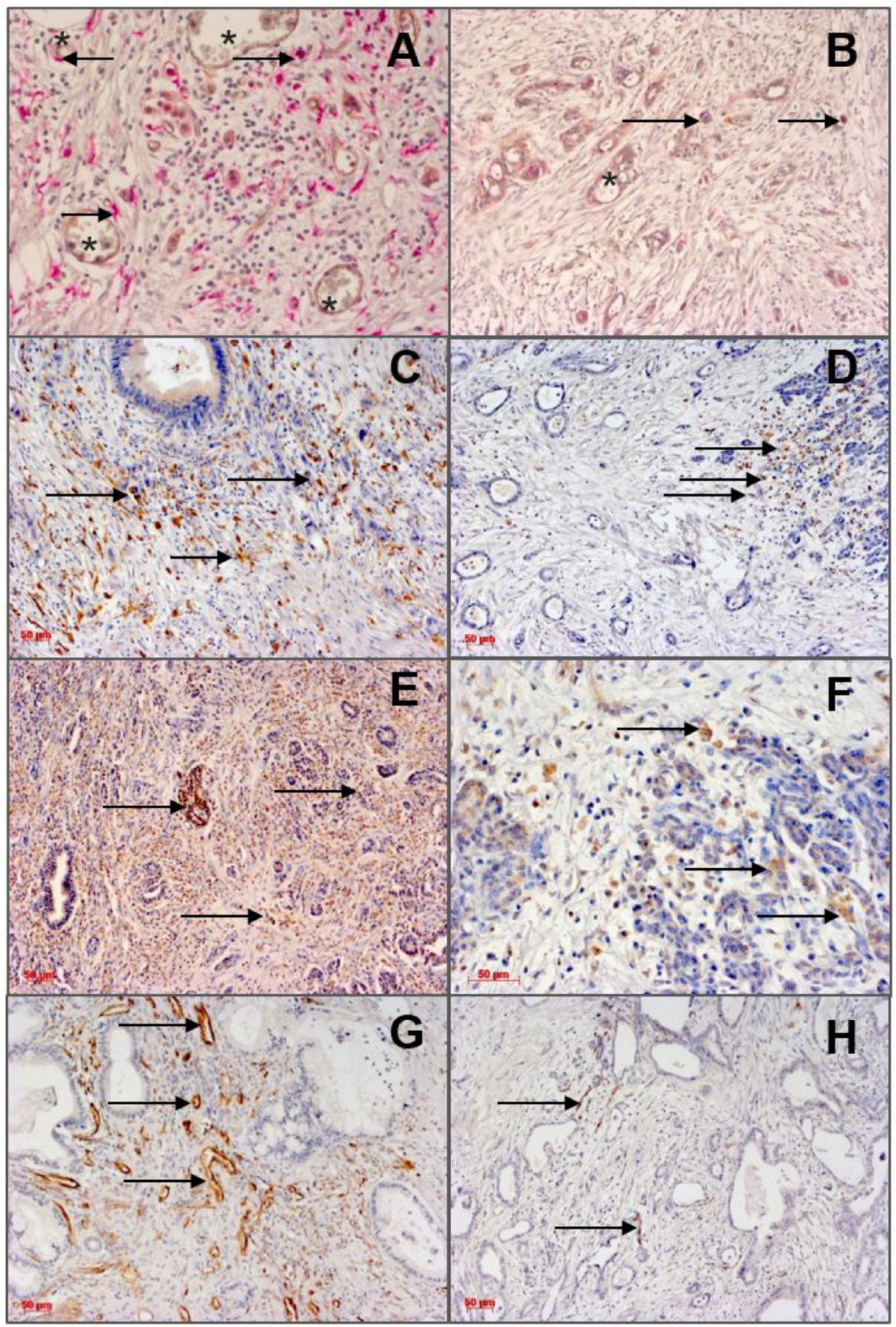

Figure 1: Immunohistological detection of angiopoietins and infiltrating monocytes/macrophages (left column: high density; right column: low density) in TCA of PDAC specimens. Arrows indicate positive staining, asterisks indicate microvessels. Scale bar $50 \mu \mathrm{m}$. (A): High density of TIE2+ monocytes in the tumor central areas (TCA). PDAC revealed a homogenous infiltration pattern of these cells with preference for the perivascular areas. (B): Low density of TIE2+ monocytes (arrows). (C): High density of CD163+ TAMs. (D): Low density of CD163+ TAMs. (E) High Ang-2 expression. (F): Low Ang-2 expression. (G): CD31+microvessels (high microvascular density, high MVD. (H): Low MVD. 
characteristics and survival in human PDAC. Consequently, further research is required to investigate molecular mechanisms linking cancer immunity to TEMs functions, phenotype and polarization state.

\section{MATERIALS AND METHODS}

\section{Patients and tumor samples}

A total of 106 patients who underwent major pancreatectomy for pancreatic adenocarcinoma at the Department of Visceral-, Transplantation-, Thoracic- and Vascular Surgery, University Hospital Leipzig, Leipzig, Germany were included in the study. Adenocarcinoma of the pancreas was confirmed histopathologically and classified according to the Union for International Cancer Control (UICC) classification. This study was carried out in accordance with the recommendations of the Ethics Committee of the Medical Faculty of the Leipzig University (no. 234-14-14072014).

In all patients, pancreas resection was with curative intent and none of the patients received neoadjuvant radioand/or chemotherapy prior to surgery. None of the patients died in the postoperative period. Tissue blocks embedding a representative sample of the tumor were retrieved from the files of the Institute of Pathology. Histological diagnosis of the primary tumor stage and nodal status were determined by hematoxylin and eosin (H\&E) stained sections. Histological evaluation of all specimens was performed by two investigators (CP and GA) with formal training in histopathology, and an independent pathologist (KS), without any knowledge of prognosis or clinicopathological variables. Paraffin-embedded, formalin-fixed tumor samples were used.

\section{Immunohistology}

Protocols for immunohistology and quantification of cellular infiltrates in paraffin-embedded, formalin-fixed tissue samples have been published previously [4, 22, 23]. Table 5 summarizes the antibodies and staining conditions used. Briefly, $5 \mu \mathrm{m}$ tumor sections were dewaxed and rehydrated. After antigen retrieval and blocking of the endogenous peroxidase or alkaline phosphatase activity, the sections were consecutively incubated with the primary and enzyme-labeled secondary antibody and the respective
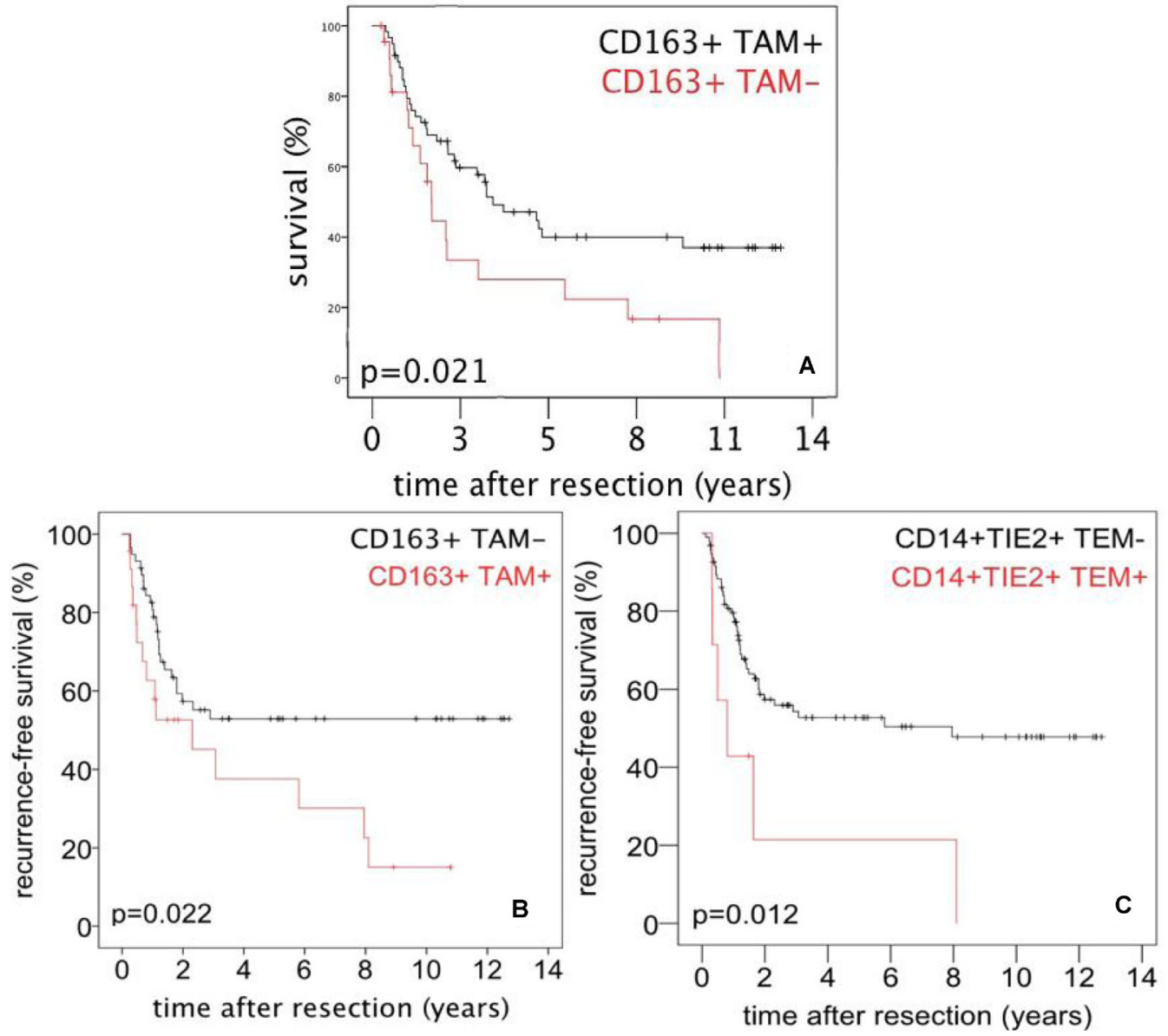

Figure 2: Survival after surgery for PDAC referred to tumor infiltrating monocytes/macrophages. (A) Overall survival after surgery for PDAC referred to presence or absence of $\mathrm{CD} 163^{+} \mathrm{TAMs}$ in the tumor infiltration front (TIF). (B) Recurrence-free survival after surgery for PDAC referred to presence or absence of CD163+ TAMs in TIF. (C) Recurrence-free survival after surgery for PDAC referred to presence or absence of TEMs in the tumor central area (TCA). 
Table 5: Antibodies used for immunostaining

\begin{tabular}{|c|c|c|c|c|c|c|c|c|}
\hline Antigen & $\mathbf{m} / \mathbf{p}$ & clone & species & company & $\begin{array}{l}\text { secondary } \\
\text { antibody }\end{array}$ & company & substrate & $\begin{array}{l}\text { antigen } \\
\text { retrieval }\end{array}$ \\
\hline angiopoetin-1 & $\mathrm{p}$ & - & goat & $\begin{array}{l}\text { Santa Cruz, } \\
\text { Dallas, USA }\end{array}$ & $\begin{array}{l}\text { rabbit anti- } \\
\text { goat-Ig }\end{array}$ & Agilent & DAB & $\begin{array}{c}10 \mathrm{mM} \\
\text { citrate, } \mathrm{pH} \\
5.5\end{array}$ \\
\hline angiopoetin-2 & $\mathrm{p}$ & - & goat & $\begin{array}{l}\text { Santa Cruz, } \\
\text { Dallas, USA }\end{array}$ & $\begin{array}{l}\text { rabbit anti- } \\
\text { goat-Ig }\end{array}$ & Agilent & DAB & $\begin{array}{c}10 \mathrm{mM} \\
\text { citrate, } \mathrm{pH} \\
5.5\end{array}$ \\
\hline CD14 & $\mathrm{p}$ & - & rabbit & $\begin{array}{l}\text { Sigma Aldrich, } \\
\text { Steinheim, } \\
\text { Germany }\end{array}$ & $\begin{array}{c}\text { anti-rabbit Ig/ } \\
\text { AP }\end{array}$ & $\begin{array}{c}\text { Vector } \\
\text { Laboratorie, } \\
\text { Burlingame, } \\
\text { USA }\end{array}$ & $\begin{array}{l}\text { Vector } \\
\text { Red AP }\end{array}$ & $\begin{array}{c}\text { target } \\
\text { retrieval } \\
\text { solution } \mathrm{pH} \\
6.1\end{array}$ \\
\hline CD31 & $\mathrm{m}$ & JC70A & mouse & $\begin{array}{c}\text { Agilent } \\
\text { Technologies } \\
\text { Deutschland } \\
\text { GmbH, } \\
\text { Waldbronn, } \\
\text { Germany }\end{array}$ & $\begin{array}{l}\text { anti-mouse-Ig/ } \\
\text { peroxidase }\end{array}$ & Vector & DAB & $\begin{array}{c}\text { Tris/EDTA } \\
\text { pH } 9.0\end{array}$ \\
\hline CD68 & $\mathrm{m}$ & $\begin{array}{l}\text { PG- } \\
\text { M1 }\end{array}$ & mouse & Agilent & $\begin{array}{l}\text { anti-mouse-Ig/ } \\
\text { peroxidase }\end{array}$ & Vector & DAB & $\begin{array}{c}\text { Tris/EDTA } \\
\text { pH } 9.0\end{array}$ \\
\hline CD163 & $\mathrm{m}$ & 10D6 & mouse & $\begin{array}{c}\text { Leica } \\
\text { Biosystems, } \\
\text { Newcastle Upon } \\
\text { Tyne, UK }\end{array}$ & $\begin{array}{l}\text { anti-mouse-Ig/ } \\
\text { peroxidase }\end{array}$ & Vector & DAB & $\begin{array}{c}10 \mathrm{mM} \\
\text { citrate, } \mathrm{pH} \\
5.5\end{array}$ \\
\hline TIE2 & $\mathrm{p}$ & - & goat & $\begin{array}{l}\text { R\&D Sys, } \\
\text { Minneapolis, } \\
\text { USA }\end{array}$ & $\begin{array}{l}\text { anti-goat-Ig/ } \\
\text { peroxidase }\end{array}$ & Vector & DAB & $\begin{array}{c}\text { target } \\
\text { retrieval } \\
\text { solution } \mathrm{pH} \\
6.1\end{array}$ \\
\hline
\end{tabular}

Abbreviations: AP: alkaline phosphatase; DAB: 3,3'-diaminobenzidine; m:monoclonal; MVD: microvessel density p: polyclonal; TAM: tumor associated macrophage; TEM: Tie2-expressing monocyte.

enzymatic substrate. Sections were counterstained with hematoxylin. Specificity controls were performed without the primary antibody.

\section{Density quantification of cellular infiltrates, angiopoietins and tumor microvascular density}

To quantify TEMs, the sections were double immunostained for CD14 and TIE2 [20]. Staining of CD68 and CD163 was used to quantify TAMs or M2-polarized TAMs, respectively. Sections were stained for angiopoietin-1 and angiopoietin-2 to estimate their expression in tumor cells. After immunostaining, the whole tumor area was thoroughly inspected for the presence of antibody-positive cells. Infiltrating immune cells and angiopoietin-positive tumor cells were categorized as negative/absent in up to $5 \%$ positive cells $(0-5 \%$ positive cells, score 0$)$ and positive/ present ( $>5 \%$ positive cells, score 1$)$. Subsequently, patients were divided into two groups either to be negative or positive for TEMs, $\mathrm{CD}^{+} 8^{+}$or $\mathrm{CD} 163^{+} \mathrm{TAMs}$, and angiopoietin-1 or $-2^{+}$tumor cells (Table 4 ). TIF could be microscopically visualized in 82 out of $106(82 / 106)$ patients.
Microvessels were identified by CD31 expression. Quantification of $\mathrm{CD} 31^{+}$microvessels was performed as described [30]. Briefly, the area of highest MVD, that is the vascular hot spot, was located by scanning the whole tumor section. All microvessels were counted in this spot. MVD was calculated from the number of vessels in ten random optical fields/section. MVD was categorized as low or high (MVD ${ }^{\text {low }}$ and $M V D^{\text {high }}$; cut-off value: 50 microvessels/10 optical fields, Table 4).

\section{Statistical analysis}

Survival analysis, univariate analysis and Kaplan-Meier curves were generated with the SPSS software program (Version 23.0.0.0/Year 2015). Comparison of categorical and continuous variables was performed using the Chi2-test and the Wilcoxontest, respectively. Survival data were compared with the log-rank-test. Variables with a significant influence on survival in the univariate analysis were entered into a Cox regression analysis. A difference was considered significant for $p<0.05$. 


\section{Abbreviations}

Ang: angiopoietin; DAMP: damage associated molecular patterns; HCC: hepatocellular carcinoma; H\&E: hematoxylin and eosin; mAb: monoclonal antibody; TAM: tumor associated macrophage; TCA: tumor central area; TEM: Tie2-expressing monocytes; TIF: tumor infiltrating front; TME: tumor microenvironment; UICC: Union for International Cancer Control; VEGF: vascular endothelial growth factor.

\section{Author contributions}

Georgi Atanasov: Significant contributions to the conception of the study, to the generation, analysis, and interpretation of the data, and to preparing the manuscript.

Charlotte Pötner: Significant contributions to the generation and analysis of the data, and to preparing the manuscript. Gabriela Aust: critical review of the manuscript, resources. Katrin Schierle: Significant contributions to analysis and interpretation of the data, and to preparing the manuscript. Corinna Dietel: Significant contributions to the generation and analysis of the data, and to preparing the manuscript. Christian Benzing: Significant contributions to conception of the study and to preparing the manuscript. Felix Krenzien: Significant contributions to conception of the study and to preparing the manuscript. Michael Bartels: Significant contributions to preparing the manuscript. Uwe Eichfeld: Significant contributions to preparing the manuscript. Moritz Schmelzle: Significant contributions to the conception of the study, to the analysis and interpretation of the data, and to preparing the manuscript. Marcus Bahra: Significant contributions to preparing the manuscript. Andreas Pascher: Significant contributions to preparing the manuscript. Georg Wiltberger: Significant contributions to the conception of the study, to the generation, analysis and interpretation of the data, and to preparing the manuscript.

\section{ACKNOWLEDGMENTS}

The authors are most grateful to Dr. Kiruthikah Thillai (Cancer Studies, King's College London, UK, and UK Department of Medical Oncology, Guy's \& St Thomas' NHS Trust, London, UK) for the essential collegial support and reviewing the manuscript as native speaker.

\section{CONFLICTS OF INTEREST}

The authors declare that they have no competing interests related to the work.

\section{FUNDING}

The work presented in this paper was made possible by funding from the Berlin Institute of Health (BIH) to GA and from the German Federal Ministry of Education and Research (BMBF 1315883) to MS. Georgi Atanasov is participant of the BIH Charité Clinician Scientist Program funded by the Charité/Universitätsmedizin Berlin and the Berlin Institute of Health.

\section{REFERENCES}

1. Murray PJ. Nonresolving macrophage-mediated inflammation in malignancy. FEBS J. 2018; 285:641-653.

2. Genard G, Lucas S, Michiels C. Reprogramming of TumorAssociated Macrophages with Anticancer Therapies: Radiotherapy versus Chemo- and Immunotherapies. Front Immunol. 2017; 8:828. https://doi.org/10.3389/ fimmu.2017.00828.

3. Allard B, Longhi MS, Robson SC, Stagg J. The ectonucleotidases CD39 and CD73: novel checkpoint inhibitor targets. Immunol Rev. 2017; 276:121-44. https:// doi.org/10.1111/imr.12528.

4. Atanasov G, Dietel C, Feldbrügge L, Benzing C, Krenzien F, Brandl A, Mann E, Englisch JP, Schierle K, Robson SC, Splith K, Morgul MH, Reutzel-Selke A, et al. Tumor necrosis and infiltrating macrophages predict survival after curative resection for cholangiocarcinoma. OncoImmunology. 2017; 6:e1331806. https://doi.org/10.1 080/2162402X.2017.1331806.

5. An T, Sood U, Pietruk T, Cummings G, Hashimoto $\mathrm{K}$, Crissman JD. In situ quantitation of inflammatory mononuclear cells in ductal infiltrating breast carcinoma. Relation to prognostic parameters. Am J Pathol. 1987; 128:52-60.

6. Bingle L, Brown NJ, Lewis CE. The role of tumourassociated macrophages in tumour progression: implications for new anticancer therapies. J Pathol. 2002; 196:254-65. https://doi.org/10.1002/path.1027.

7. Mantovani A, Allavena P, Sica A. Tumour-associated macrophages as a prototypic type II polarised phagocyte population: role in tumour progression. Eur J Cancer. 2004; 40:1660-67. https://doi.org/10.1016/j.ejca.2004.03.016.

8. Tsutsui S, Yasuda K, Suzuki K, Tahara K, Higashi H, Era S. Macrophage infiltration and its prognostic implications in breast cancer: the relationship with VEGF expression and microvessel density. Oncol Rep. 2005; 14:425-31.

9. Condeelis J, Pollard JW. Macrophages: obligate partners for tumor cell migration, invasion, and metastasis. Cell. 2006; 124:263-66. https://doi.org/10.1016/j.cell.2006.01.007.

10. Pollard JW. Macrophages define the invasive microenvironment in breast cancer. J Leukoc Biol. 2008; 84:623-30. https://doi.org/10.1189/jlb.1107762.

11. Ohno S, Inagawa H, Dhar DK, Fujii T, Ueda S, Tachibana M, Suzuki N, Inoue M, Soma G, Nagasue N. The degree of macrophage infiltration into the cancer cell nest is a significant predictor of survival in gastric cancer patients. Anticancer Res. 2003; 23:5015-22. 
12. Forssell J, Oberg A, Henriksson ML, Stenling R, Jung A, Palmqvist R. High macrophage infiltration along the tumor front correlates with improved survival in colon cancer. Clin Cancer Res. 2007; 13:1472-79. https://doi. org/10.1158/1078-0432.CCR-06-2073.

13. Ohno S, Ohno Y, Suzuki N, Kamei T, Koike K, Inagawa H, Kohchi C, Soma G, Inoue M. Correlation of histological localization of tumor-associated macrophages with clinicopathological features in endometrial cancer. Anticancer Res. 2004; 24:3335-42.

14. Wang J, Chen J, Guo Y, Wang B, Chu H. Strategies targeting angiogenesis in advanced non-small cell lung cancer. Oncotarget. 2017; 8:53854-72. https://doi.org/10.18632/ oncotarget. 17957.

15. Balkwill F, Charles KA, Mantovani A. Smoldering and polarized inflammation in the initiation and promotion of malignant disease. Cancer Cell. 2005; 7:211-17. https://doi. org/10.1016/j.ccr.2005.02.013.

16. Hashimoto E, Kage K, Ogita T, Nakaoka T, Matsuoka R, Kira Y. Adenosine as an endogenous mediator of hypoxia for induction of vascular endothelial growth factor mRNA in U-937 cells. Biochem Biophys Res Commun. 1994; 204:318-24. https://doi.org/10.1006/bbrc.1994.2462.

17. Semenza GL. Angiogenesis in ischemic and neoplastic disorders. Annu Rev Med. 2003; 54:17-28. https://doi. org/10.1146/annurev.med.54.101601.152418.

18. De Palma M, Murdoch C, Venneri MA, Naldini L, Lewis CE. Tie2-expressing monocytes: regulation of tumor angiogenesis and therapeutic implications. Trends Immunol. 2007; 28:519-24. https://doi.org/10.1016/j.it.2007.09.004.

19. De Palma M, Venneri MA, Roca C, Naldini L. Targeting exogenous genes to tumor angiogenesis by transplantation of genetically modified hematopoietic stem cells. Nat Med. 2003; 9:789-95. https://doi.org/10.1038/nm871.

20. Venneri MA, De Palma M, Ponzoni M, Pucci F, Scielzo C, Zonari E, Mazzieri R, Doglioni C, Naldini L. Identification of proangiogenic TIE2-expressing monocytes (TEMs) in human peripheral blood and cancer. Blood. 2007; 109:527685. https://doi.org/10.1182/blood-2006-10-053504.

21. van der Bij GJ, Bögels M, Oosterling SJ, Kroon J, Schuckmann DT, de Vries HE, Meijer S, Beelen RH, van Egmond M.
Tumor infiltrating macrophages reduce development of peritoneal colorectal carcinoma metastases. Cancer Lett. 2008; 262:77-86. https://doi.org/10.1016/j.canlet.2007.11.040.

22. Atanasov G, Hau HM, Dietel C, Benzing C, Krenzien F, Brandl A, Wiltberger G, Matia I, Prager I, Schierle K, Robson SC, Reutzel-Selke A, Pratschke J, et al. Prognostic significance of macrophage invasion in hilar cholangiocarcinoma. BMC Cancer. 2015; 15:790. https:// doi.org/10.1186/s12885-015-1795-7.

23. Atanasov G, Hau HM, Dietel C, Benzing C, Krenzien F, Brandl A, Englisch JP, Wiltberger G, Schierle K, Robson SC, Reutzel-Selke A, Jonas S, Pascher A, et al. Prognostic significance of TIE2-expressing monocytes in hilar cholangiocarcinoma. J Surg Oncol. 2016; 114:91-98. https://doi.org/10.1002/jso.24249.

24. Tacke F. Targeting hepatic macrophages to treat liver diseases. J Hepatol. 2017; 66:1300-12. https://doi. org/10.1016/j.jhep.2017.02.026.

25. Coussens LM, Werb Z. Inflammation and cancer. Nature. 2002; 420:860-67. https://doi.org/10.1038/nature01322.

26. de Visser KE, Eichten A, Coussens LM. Paradoxical roles of the immune system during cancer development. Nat Rev Cancer. 2006; 6:24-37. https://doi.org/10.1038/nrc1782.

27. Crawford M, Brawner E, Batte $\mathrm{K}, \mathrm{Yu}$ L, Hunter MG, Otterson GA, Nuovo G, Marsh CB, Nana-Sinkam SP. MicroRNA-126 inhibits invasion in non-small cell lung carcinoma cell lines. Biochem Biophys Res Commun. 2008; 373:607-12. https://doi.org/10.1016/j.bbrc.2008.06.090.

28. Saharinen P, Eklund L, Alitalo K. Therapeutic targeting of the angiopoietin-TIE pathway. Nat Rev Drug Discov. 2017; 16:635-61. https://doi.org/10.1038/nrd.2016.278.

29. Schulz P, Fischer C, Detjen KM, Rieke S, Hilfenhaus G, von Marschall Z, Böhmig M, Koch I, Kehrberger J, Hauff P, Thierauch KH, Alves F, Wiedenmann B, Scholz A. Angiopoietin-2 drives lymphatic metastasis of pancreatic cancer. FASEB J. 2011; 25:3325-35. https://doi. org/10.1096/fj.11-182287.

30. Hasan J, Byers R, Jayson GC. Intra-tumoural microvessel density in human solid tumours. Br J Cancer. 2002; 86:1566-77. https://doi.org/10.1038/sj.bjc.6600315. 